\title{
Change in Organic and Inorganic Components of Hepatopancreas, Muscles and Haemolymph of Procambarus clarkii during the Molting Cycle
}

\author{
Ghanem $^{\text {a* }}$, M.H.; Zaahkouk, S.A.; El-Sayed, A.A.; El-Damhougy, Kh.A., Amer, M.A. \\ Zoology Department, Faculty of Science, Al-Azhar University, Nasr city, Cairo, Egypt \\ *ghanemhamed@yahoo.com
}

\begin{abstract}
:
Aims: To gives information's about internal changes associated with molting process of crayfish, Procambarus clarkii, from the Egyptian freshwaters. Internal changes in crayfish P. clarkii were studied from hatchlings to adult stage associated with molting cycle included (a) Changes in inorganic components (biominerals) especially $\mathrm{Ca}, P \& \mathrm{Mg}$ and (b) Organic components especially total protein \& total cholesterol.

Methodology: The specimens of the red swamp crayfish, P. clarkii, were collected alive from the River Nile tributaries at Al-Kanater Al-Khairiya, Qalyoubia Governorate during the period from May 2013 to September 2014 for investigate the internal changes during molting cycle. All specimens were kept for acclimatization under the laboratory conditions in the glass aquaria aerated with air pumps at room ambient temperature (21$23{ }^{\circ} \mathrm{C}$ ) and at $\mathrm{pH}$ ranged between 7.3-7.5. Water was exchanged weekly with aerated water under the same conditions.

Results: Data revealed that, internal changes in adult crayfish, P. clarkii, involved physiological changes as; the molting stages were also characterized by internal changes, represented by sharp fluctuations in the levels of biominerals and organic components in hepatopancreas, muscle and haemolymph which play an important role in molting cycle. The present study declared that, the increasing of biominerals in haemolymph in narrow range indicating the fact that haemolymph is not storage organ but is the carrier one. Also, data showed that, hepatopancreas plays an important role during the molting process and considers a main storage site for the most important inorganic and organic components. Statistical analysis indicated that, there are differences ranges in organic and inorganic components between the different molting stages.
\end{abstract}

Keywords: cray fish, molting stages, biochemical parameters.

\section{INTRODUCTION}

Crayfish, Procambarus clarkii had been introduced during the last decades of the $20^{\text {th }}$ century. The only available explanation is that the initial access and colonization of $P$. clarkii started at commercial aquaculture farm in Giza (Manial- Sheiha), in the early 1980's, when the first immigrants of this species were introduced from USA. This project was shortly terminated due to unknown problems [1].

Crayfish like other decapods crustaceans, have some biological characteristics that make it potentially important species for aquaculture, among which: adaptation to conditions of captivity and handling; accept artificial feeds of different origins (shrimp, fish, aquatic plants, vegetables, ...etc.) and have a relatively short life cycle (two years or less); breeds in captivity at early age (about four months with reproduction all year; and some females have more than one spawning per year [2].

The fast widespread for $P$. clarkii is attributed to high adaptability for burrowing in the soft bottom, tolerance of aerial exposure, rapid growth, high fecundity and disease resistance [3]. However, the sudden occurrence in the Egyptian freshwaters caused several problems represented mainly by attacked fish nets and consumed eggs of commercial fishes, destruction of irrigation systems by their burrowing behavior leading to tunnels formation [4].

The physiological characteristics of crayfishes allow them to adapt to extreme climatic variations, diversifying their potential habitats, ensuring reproduction and contributing to progeny survival under adverse conditions. This occurs under natural or artificial conditions, making them promising 
organisms for use in aquaculture systems [5]. Molting occurs in all arthropods, from insects to crustaceans. It is essential for growth, reproduction and metamorphosis. Molting occurs in cycles and involves the shedding of hard skeleton to expose a soft new shell. There are three areas within molting control that have been identified as having potential commercial significant, these are: 1- Controlling the timing of molt; 2- Manipulating the synchrony of molting within population (mass molting); and 3 -Controlling the process of shell hardening [6].

Molting cycle influences many aspects of crustacean biology, including animal morphology, cellular metabolism, physiology and behavior $[\mathbf{7 , 8 , 9}$. Crustaceans must be first loose the connections between their living tissues and old cuticle, then they move out rapidly from the confines of this cuticle by taking up water to expand the new, flexible exoskeleton, and quickly harden it was described by Lowery [8], so it provides protection and support for locomotion. The actual act of shedding the old exoskeleton, ecdysis, is the most obvious manifestation of the molt cycle. However, it comprises only a few minutes of a cycle that in some crustacean species takes from few days or week (in juveniles) to few months and even a year or more in adults of some species to complete. This cycle divides into several major stages with numerous substages $[7,10]$.

The appearance of $P$. clarkii in the Egyptian environment had treated through several studies comprising life cycle and reproduction [11], mode of life, natural growth rates and survival rates for juveniles at laboratory conditions [12], factors affecting molting processes and eyestalk ablation of juveniles [13], food and feeding behavior [14], distribution [15, 16].

Knowledge for the course of molting cycle stages is highly important for the understanding of various aspects of crustacean biology, including physiology and biochemistry $[17,18]$. Presence of intensive farming for food and heavy industrialization for production of goods to meet the need of growing population has led to problem of pollution. Therefore, the present study aims to evaluate the internal changes in organic and inorganic components during the different molting stages in adults and subadult individuals to introduce full information on this species for using in aquaculture and marketing as a new high quality crustacean organism and cheap source of animal proteins in Egypt.

\section{Materials ANd Methods}

\subsection{Materials}

A total of 100 specimens of the red swamp crayfish, $P$. clarkii, were collected alive from the River Nile tributaries at Al-Kanater Al- Khairiya, Qalyoubia Governorate during the period from May 2013 to September 2014. The collected specimens were used for investigate internal changes during molting cycle.

All specimens were kept for acclimatization under the laboratory conditions in the Faculty of Science Al-Azhar University. Ten specimens were kept in each glass aquaria $(60 \mathrm{X} 40 \mathrm{X} 40 \mathrm{~cm})$ containing at least $50 \mathrm{~L}$ fresh water, aerated with air pumps at room ambient temperature $\left(21-23^{\circ} \mathrm{C}\right)$ and at $\mathrm{pH}$ ranged between 7.3- 7.5. Water was exchanged weekly with aerated water under the same conditions. All animals fed frozen fish meat every three days as $3 \%$ of the biomass and were used for the following measurements:

During the molting stages (intermolting, premolting and postmolting stages), the intermolting stage showed a complete formation of setal cone, appear arranged in one row at the bases of setae, and beings pigmented with deep reddish brown colour. Epidermal tissues appear attached to setal cone and spreading between it. Complete retraction of setal matrix $(\mathrm{Sm})$ was observed, particularly near the setal bases, while setal lumens ( $\mathrm{Sl}$ ) being almost empty.

However, Premolt (Stage D) beings the most important molting stage and was characterized by rapid morphological and physiological changes during juvenile life span. Therefore, it divides, based on these rapid events, into four substages as following: - Substage D1: Pigments appear retracted within epidermal layer at this substage. Setal lumens seem clear without setal matrices and appearance of internal cone. Substage D2: This substage was characterized by the appearance of straight narrow white zone between the epidermal tissue and setal cones, indicating the formation of new cuticle, beginning of formation of newly seta. Pigments are variable and being dispersed within epidermis. Substage D3: This substage was defined by the disappearance of setal cones, accompanied with retracted pigment and initiation of new setae within each setal base. Pigments were retracted from the bases of setal nodes and leave old cuticle. A wavy-shaped, dark edge appears between proximal 
border of epidermal tissues and bases of setae. Substage D4: During this substage, intense pigment retraction from old cuticular setae was observed leading to faint cuticule. These pigments increase in the wavy- like edge at the proximal border of epidermal tissue appears associated with highly widened clear zone between epidermal tissue and old setal bases (appearance of apolysis). New setae were clearly formed parallel to edge of epidermal tissue.

Postmolt stages (Stages A \& B): During post molt stage A (newly molt), new setae become clear, with less distinct setal lumens, bases and nodes. Epidermis was faint, appears with less dense pigments and setal lumens are filled with setal matrix. On the other hand, at the onset of stage B (recently molt), setal lumens, base and nodes become more distinct. Epidermal pigments become denser and darker than the previous stage. Inside setal lumens, setal matrices begun to retract towards the bases of setae.

\subsection{Methods for Changes in Inorganic and Organic Components}

The determined animals were classified externally and anatomically into main five molting stages according to Warner [7], Lowery [8], modified by Promwikorn et al. [10].

Haemolymph was withdrawn from live individuals through arthropodal membrane in the dorsal surface between carapace end and first abdominal segment at each stage, and then dissected to get out hepatopancreas and muscles. The removed organs put in isotonic saline solution, then weighted and preserved under -18 to $-20{ }^{\circ} \mathrm{C}$.

For estimation of minerals and organic components, a piece of each preserved organ was weighting and put in appropriate amount of saline solution, then homogenized and used for estimation of total protein, cholesterol, calcium, phosphorous and magnesium. Commercial kits purchased from Spectrum Company were used for measuring these items.

In the tissues and haemolymph, total proteins and cholesterol were determined respectively according to the methods of Doumas [19], Naito [20]. While, minerals comprising phosphorous, calcium and magnesium were estimated respectively according to Daly and Ertingshausen [21], Cowley and Clin [22], Thomas [23].

\subsection{Statistical Analysis}

Statistical analyses using student t-test were used to test the differences between values of these parameters during different molting stages in hepatopancreas, muscles and haemolymph with program (Minitab, version 14). Differences among treatments were considered significant at $p<0.05$. The results were expressed as means $\pm \mathrm{SE}$ (standard error).

\section{RESUlTS AND DisCUSSION}

\subsection{Changes in Biominerals (Inorganic Components)}

\subsubsection{Calcium}

Crayfishes like other decapods crustaceans, have some biological characteristics that make them potentially important species for aquaculture and have a relatively short life cycle takes two years or less [3,24]. Molting cycle is important process during life cycle of all crustaceans particularly the freshwater crayfishes. It influences many aspects of crustacean biology, including animal morphology, cellular metabolism, physiology, reproduction and behavior. Growth in crustaceans is not a continuous process, but takes place in successive steps during certain periods $[7, \mathbf{8}, \mathbf{9}]$.

External changes can be used for determining molt stages in P. clarkii, further studies particularly physiological and chemical analyses are necessary to give complete information on the very complicated molt cycle of this species and other crustaceans used in aquaculture. Therefore, the internal changes associated with molt cycle involved anatomical and biochemical changes in hepatopancreas, muscle and haemolymph were investigated.

\section{- Changes in The Hepatopancreas During Molting}

Data presented in Table (1) showed significant fluctuations in calcium ratios within hepatopancreas during the different molting stages. The highest ratio was recorded during the premolt substage $\mathrm{D}_{3}$ $(16.72 \pm 4.37 \mathrm{mg} \%)$ and declined remarkably to the lowest one $(4.64 \pm 0.89 \mathrm{mg} \%)$ in the newly molt (Stage, A). Its ratios were increased slightly from $10.03 \pm 0.97 \mathrm{mg} \%$ during the intermolt stage $\mathrm{C}$ to 
$10.91 \pm 1.96 \mathrm{mg} \%$ at early premolt substage $\mathrm{D}_{1}$ without any significance difference. However, a slight decline was recorded during the late successive premolt substages $\left(\mathrm{D}_{3}\right.$ and $\left.\mathrm{D}_{4}\right)$ with high significant difference between the intermolt and late premolt substage $\mathrm{D}_{4}$ (T-test $=2.91, \mathrm{P}<0.01$ ) as shown in Table (3) leading to sharp decline during the post molt stages A\&B.

Table1. Changes in calcium, phosphorous and magnesium within hepatopancreas, muscles and haemolymph of the cray fish, procamborus clarkii during the molting stages

\begin{tabular}{|c|c|c|c|c|c|c|c|c|c|c|}
\hline \multirow{2}{*}{\multicolumn{2}{|c|}{\begin{tabular}{|l|} 
Minerals \\
Molting \\
stages
\end{tabular}}} & \multicolumn{3}{|c|}{ Calcium mg\% } & \multicolumn{3}{|c|}{ Phosphorous mg/g } & \multicolumn{3}{|c|}{ Magnesium $\mathrm{mg} / \mathrm{g}$} \\
\hline & & $\begin{array}{c}\text { Hepatopan } \\
\text { creas }\end{array}$ & Muscles & $\begin{array}{c}\text { Haemolym } \\
\text { ph }\end{array}$ & $\begin{array}{l}\text { Hepatopan } \\
\text { creas }\end{array}$ & Muscles & $\begin{array}{c}\text { Haemolym } \\
\text { ph }\end{array}$ & $\begin{array}{l}\text { Hepatopan } \\
\text { creas }\end{array}$ & Muscles & $\begin{array}{c}\text { Haemolym } \\
\text { ph }\end{array}$ \\
\hline $\begin{array}{c}\text { Inter- } \\
\text { molt }\end{array}$ & $\mathrm{C}$ & $\begin{array}{l}10.03 \\
\pm 0.97\end{array}$ & $\begin{array}{r}10.51 \\
\pm 1.64 \\
\end{array}$ & $\begin{array}{l}14.82 \\
\pm 2.04\end{array}$ & $\begin{array}{c}0.68 \\
\pm 0.05 \\
\end{array}$ & $\begin{array}{c}0.52 \\
\pm 0.08\end{array}$ & $\begin{array}{c}1.35 \\
\pm 0.44\end{array}$ & $\begin{array}{c}0.09 \\
\pm 0.01\end{array}$ & $\begin{array}{c}0.06 \\
\pm 0.01\end{array}$ & $\begin{array}{c}3.50 \\
\pm 0.16\end{array}$ \\
\hline \multirow{4}{*}{$\begin{array}{l}\text { Pre- } \\
\text { molt }\end{array}$} & $\mathrm{D}_{1}$ & $\begin{array}{l}10.91 \\
\pm 1.96\end{array}$ & $\begin{array}{c}7.31 \\
\pm 1.58\end{array}$ & $\begin{array}{l}16.30 \\
\pm 0.42\end{array}$ & $\begin{array}{c}0.83 \\
\pm 0.23\end{array}$ & $\begin{array}{c}0.36 \\
\pm 0.11\end{array}$ & $\begin{array}{c}2.77 \\
\pm 0.47\end{array}$ & $\begin{array}{c}0.19 \\
\pm 0.04\end{array}$ & $\begin{array}{c}0.06 \\
\pm 0.01\end{array}$ & $\begin{array}{c}3.58 \\
\pm 0.02\end{array}$ \\
\hline & $\mathrm{D}_{2}$ & $\begin{array}{r}14.93 \\
\pm 2.56\end{array}$ & $\begin{array}{r}9.40 \\
\pm 2.41\end{array}$ & $\begin{array}{l}16.89 \\
\pm 0.11\end{array}$ & $\begin{array}{c}0.58 \\
\pm 0.18\end{array}$ & $\begin{array}{c}0.44 \\
\pm 0.11\end{array}$ & $\begin{array}{c}1.98 \\
\pm 0.25\end{array}$ & $\begin{array}{c}0.17 \\
\pm 0.04\end{array}$ & $\begin{array}{c}0.07 \\
\pm 0.02\end{array}$ & $\begin{array}{c}3.67 \\
\pm 0.23\end{array}$ \\
\hline & $\mathrm{D}_{3}$ & $\begin{array}{r}16.72 \\
\pm 4.37 \\
\end{array}$ & $\begin{array}{c}9.97 \\
\pm 2.78 \\
\end{array}$ & $\begin{array}{l}16.23 \\
\pm 0.53\end{array}$ & $\begin{array}{c}0.80 \\
\pm 0.29 \\
\end{array}$ & $\begin{array}{c}0.40 \\
\pm 0.09 \\
\end{array}$ & $\begin{array}{c}1.63 \\
\pm 0.66\end{array}$ & $\begin{array}{c}0.18 \\
\pm 0.05\end{array}$ & $\begin{array}{c}0.08 \\
\pm 0.01\end{array}$ & $\begin{array}{c}3.59 \\
\pm 0.51 \\
\end{array}$ \\
\hline & $\mathrm{D}_{4}$ & $\begin{array}{c}14.8 \\
\pm 0.28\end{array}$ & $\begin{array}{l}12.81 \\
\pm 2.11\end{array}$ & $\begin{array}{l}16.93 \\
\pm 0.01\end{array}$ & $\begin{array}{c}0.40 \\
\pm 0.18\end{array}$ & $\begin{array}{c}0.46 \\
\pm 0.21\end{array}$ & $\begin{array}{c}1.61 \\
\pm 0.24\end{array}$ & $\begin{array}{c}0.14 \\
\pm 0.07\end{array}$ & $\begin{array}{c}0.06 \\
\pm 0.01\end{array}$ & $\begin{array}{c}3.29 \\
\pm 0.54\end{array}$ \\
\hline \multirow{2}{*}{$\begin{array}{l}\text { Post- } \\
\text { molt }\end{array}$} & A & $\begin{array}{c}4.64 \\
\pm 0.89\end{array}$ & $\begin{array}{c}1.75 \\
\pm 0.01\end{array}$ & $\begin{array}{l}16.79 \\
\pm 0.28\end{array}$ & $\begin{array}{c}1.11 \\
\pm 0.21\end{array}$ & $\begin{array}{c}0.41 \\
\pm 0.18\end{array}$ & $\begin{array}{c}3.26 \\
\pm 1.64\end{array}$ & $\begin{array}{c}0.29 \\
\pm 0.03\end{array}$ & $\begin{array}{c}0.10 \\
\pm 0.01\end{array}$ & $\begin{array}{c}2.98 \\
\pm 0.13\end{array}$ \\
\hline & B & $\begin{array}{c}5.66 \\
\pm 1.08\end{array}$ & $\begin{array}{r}7.79 \\
\pm 3.38\end{array}$ & $\begin{array}{l}16.83 \\
\pm 0.06\end{array}$ & $\begin{array}{c}0.87 \\
\pm 0.12\end{array}$ & $\begin{array}{c}0.15 \\
\pm 0.07\end{array}$ & $\begin{array}{c}1.06 \\
\pm 0.21\end{array}$ & $\begin{array}{c}0.17 \\
\pm 0.03\end{array}$ & $\begin{array}{c}0.09 \\
\pm 0.02\end{array}$ & $\begin{array}{c}3.40 \\
\pm 0.41\end{array}$ \\
\hline
\end{tabular}

- Changes in the Muscles During Molting

The present data (Table 1) exhibited that, calcium concentration in the muscles took the same pattern of hepatopancreas with ratio $10.51 \pm 1.64 \mathrm{mg} \%$ in the intermolt stage C. It increased gradually during the premolt substages and reached its maximum one $(12.81 \pm 2.11 \mathrm{mg} \%)$ in the late premolt substage $\mathrm{D}_{4}$. However, calcium levels showed sharp decline to the lowest ratio $(1.75 \pm 0.01 \mathrm{mg} \%)$, just after an ecdysis during the newly molt stage A. But calcium increased again into $7.79 \pm 3.38 \mathrm{mg} \%$ during the following recently molt stage $\mathrm{B}$. This ratio was statistically different $(\mathrm{T}$-test value $=2.72, \mathrm{P}<0.05)$ compared with the intermolt stage ratios (Table 3).

Table3. $T$ - test values for biominerals, total proteins and total cholesterol in the hepatopancreas, muscles and haemolymph of $P$. clarkii during the molting stages.

\begin{tabular}{|c|c|c|c|c|c|c|c|}
\hline Molting Stages & Samples & $C * D_{1}$ & $\mathbf{C} * \mathbf{D}_{2}$ & $C * D_{3}$ & $\mathbf{C} * \mathbf{D}_{4}$ & $C^{*} \mathbf{A}$ & $\mathbf{C} * \mathbf{B}$ \\
\hline \multirow{3}{*}{ Calcium } & Hepatopancreas & $0.45 \mathrm{~ns}$ & $2.11 *$ & $2.06^{*}$ & $2.91 * *$ & $2.63^{*}$ & $2.77 *$ \\
\hline & Muscles & $1.4 \mathrm{~ns}$ & $0.37 \mathrm{~ns}$ & $0.18 \mathrm{~ns}$ & $0.79 \mathrm{~ns}$ & $2.72 *$ & $0.82 \mathrm{~ns}$ \\
\hline & Haemolymph & $0.39 \mathrm{~ns}$ & $0.56 \mathrm{~ns}$ & $0.38 \mathrm{~ns}$ & $0.57 \mathrm{~ns}$ & $0.53 \mathrm{~ns}$ & $0.54 \mathrm{~ns}$ \\
\hline \multirow{3}{*}{ Phosphorous } & Hepatopancreas & $0.73 \mathrm{~ns}$ & $0.69 \mathrm{~ns}$ & $0.57 \mathrm{~ns}$ & $2.17 *$ & $3.33 * *$ & $1.82 *$ \\
\hline & Muscles & $1.21 \mathrm{~ns}$ & $0.64 \mathrm{~ns}$ & $1.04 \mathrm{~ns}$ & $0.37 \mathrm{~ns}$ & $0.67 \mathrm{~ns}$ & $2.85^{*}$ \\
\hline & Haemolymph & $1.38 \mathrm{~ns}$ & $0.85 \mathrm{~ns}$ & $0.35 \mathrm{~ns}$ & $0.35 \mathrm{~ns}$ & $1.67 \mathrm{~ns}$ & $0.38 \mathrm{~ns}$ \\
\hline \multirow{3}{*}{ Magnesium } & Hepatopancreas & $1.49 \mathrm{~ns}$ & $2.41 *$ & $2.32 *$ & $1.16 \mathrm{~ns}$ & $5.91 * *$ & $2.96 * *$ \\
\hline & Muscles & $0.67 \mathrm{~ns}$ & $0.46 \mathrm{~ns}$ & $1.19 \mathrm{~ns}$ & $0.19 \mathrm{~ns}$ & $1.46 \mathrm{~ns}$ & $1.09 \mathrm{~ns}$ \\
\hline & Haemolymph & $0.53 \mathrm{~ns}$ & $0.61 \mathrm{~ns}$ & $0.17 \mathrm{~ns}$ & $0.36 \mathrm{~ns}$ & $2.05 \mathrm{~ns}$ & $0.23 \mathrm{~ns}$ \\
\hline \multirow{3}{*}{ Total protein } & Hepatopancreas & $0.51 \mathrm{~ns}$ & $0.11 \mathrm{~ns}$ & $0.28 \mathrm{~ns}$ & $0.12 \mathrm{~ns}$ & $0.11 \mathrm{~ns}$ & $0.28 \mathrm{~ns}$ \\
\hline & Muscles & $0.67 \mathrm{~ns}$ & $0.98 \mathrm{~ns}$ & $0.43 \mathrm{~ns}$ & $0.7 \mathrm{~ns}$ & $0.11 \mathrm{~ns}$ & $0.67 \mathrm{~ns}$ \\
\hline & Haemolymph & $0.65 \mathrm{~ns}$ & $0.78 \mathrm{~ns}$ & $1.08 \mathrm{~ns}$ & $0.12 \mathrm{~ns}$ & $0.62 \mathrm{~ns}$ & $0.19 \mathrm{~ns}$ \\
\hline \multirow{3}{*}{ Cholesterol } & Hepatopancreas & $1.37 \mathrm{~ns}$ & $1.16 \mathrm{~ns}$ & $1.89 *$ & $0.12 \mathrm{~ns}$ & $1.03 \mathrm{~ns}$ & $0.28 \mathrm{~ns}$ \\
\hline & Muscles & $0.88 \mathrm{~ns}$ & $0.81 \mathrm{~ns}$ & $0.75 \mathrm{~ns}$ & $0.42 \mathrm{~ns}$ & $0.1 \mathrm{~ns}$ & $0.70 \mathrm{~ns}$ \\
\hline & Haemolymph & $0.25 \mathrm{~ns}$ & $1.61 \mathrm{~ns}$ & $1.48 \mathrm{~ns}$ & $4.05 * *$ & $4.88 * *$ & $3.42 * *$ \\
\hline
\end{tabular}

Note: $* *=$ highly significant difference $\quad *=$ significant difference $\quad n s=$ none significant

\section{- $\quad$ Changes in the Haemolymph During Molting}

The average ratios of calcium in the haemolymph of $P$. clarkii were fluctuated between $14.82 \pm 2.04$ $\mathrm{mg} \%$ during the intermolt $\mathrm{C}$ and $16.93 \pm 0.01 \mathrm{mg} \%$ in the premolt substage $\mathrm{D}_{4}$. But a slight decline in 
Change in Organic and Inorganic Components of Hepatopancreas, Muscles and Haemolymph of Procambarus clarkii during the Molting Cycle

calcium concentration was recorded during post molt stage A, without any significance statistical differences (Tables $1 \& 3$ ).

\subsubsection{Phosphorous}

\section{- Changes in the Hepatopancreas During Molting}

The concentration of phosphorous in hepatopancreas during molting cycle (Table 1) appeared that, in the premolt substages, it was varied from $0.4 \pm 0.18 \mathrm{mg} / \mathrm{g}$ at late premolt substage $\mathrm{D}_{4}$ to $0.83 \pm 0.23$ $\mathrm{mg} / \mathrm{g}$ at substage $D_{1}$. These values are statistically different compared with the values of intermolt stage $\mathrm{C}$ ( $\mathrm{T}$-test $=2.17, \mathrm{P}<0.05)$. However, phosphorous ratio increased again to the maximum value $(1.11 \pm 0.21 \mathrm{mg} / \mathrm{g}$ ) during the post molt stage A (newly molt) which has also statistically (Table 3 ) high significant difference $(\mathrm{T}$-test $=3.33, \mathrm{P}<0.01)$.

\section{- Changes in the Muscles During Molting}

The present results (Table 1) showed that, the maximum concentrations of phosphorous in the muscle during the intermolt stage $(0.52 \pm 0.08 \mathrm{mg} / \mathrm{g})$. Phosphorous ratios declined during the premolt substages and varied from $0.36 \pm 0.11$ to $0.46 \pm 0.21 \mathrm{mg} / \mathrm{g}$. It declined slightly into $0.41 \pm 0.18 \mathrm{mg} / \mathrm{g}$ during the newly molt stage A. But, a sharp decline $(0.15 \pm 0.09 \mathrm{mg} / \mathrm{g})$ was observed during the post molt stage B (recently molt). These fluctuations were statistically significant with $\mathrm{T}$-test values $=2.85$, $\mathrm{P}<0.05$ (Table 3).

\section{- Changes in the Haemolymph During Molting}

The highest value of phosphorous in the haemolymph of $P$. clarkii was recorded during postmolt stage A and the lowest one occurred during the post molt stage B; being $3.26 \pm 1.64 \mathrm{mg} / \mathrm{dl}$ and $1.06 \pm 0.21 \mathrm{mg} / \mathrm{dl}$, respectively. No significant differences with those values of the intermolt stage $\mathrm{C}$ compared with other stages (Tables $1 \& 3$ ).

\subsubsection{Magnesium}

\section{- Changes in the Hepatopancreas During Molting}

Magnesium level in the hepatopancreas was greatly variable. It increased sharply from $0.09 \pm 0.01$ $\mathrm{mg} / \mathrm{g}$ during the intermolt stage $\mathrm{C}$ to $0.19 \pm 0.04 \mathrm{mg} / \mathrm{g}$ during the early premolt substage $\mathrm{D}_{1}$ and reached its maximum one $(0.29 \pm 0.03 \mathrm{mg} / \mathrm{g})$ during the newly molt stage A. A sharp decline to $0.17 \pm 0.03 \mathrm{mg} / \mathrm{g}$ was recorded in the successive recently molt stage B (Table 1 ).

The statistical analysis showed a high significant difference (T-test $=5.91, \mathrm{P}<0.01)$ between magnesium concentration during the intermolt stage $\mathrm{C}$ and newly molt stage $\mathrm{A}$, also there is significant difference between ratios of the intermolt and premolts stages $\mathrm{P}<0.05$ (Table 3 ).

\section{- Changes in the Muscles During Molting}

The concentrations of magnesium in the muscles were fluctuated in narrow range during the premolt stage without any significant difference within premolt substages (Tables $1 \& 3$ ). Its values varied from $0.06 \pm 0.01 \mathrm{mg} / \mathrm{g}$ at early premolt substage $\mathrm{D}_{1}$ to $0.08 \pm 0.01$ at the late premolt substage $\mathrm{D}_{3}$, and reached the maximum concentration $(0.10 \pm 0.01 \mathrm{mg} / \mathrm{g})$ during the newly molt stage A.

\section{- Changes in the Haemolymph During Molting}

The present data indicated that, the values of magnesium concentrations in haemolymph of $P$. clarkii during the molting stages were very close together. The minimum value $(2.98 \pm 0.13 \mathrm{mg} / \mathrm{dl})$ was recorded in the newly molt stage $A$. It increased to reach the maximum value $(3.67 \pm 0.23 \mathrm{mg} / \mathrm{dl})$ during the premolt substage, $\mathrm{D}_{2}$ (Table 1). Statistical analysis (Table 3) showed that, no significant differences $(\mathrm{P}>0.05)$ were detected between all inorganic minerals in the haemolymph of P. clarkii during the molting stages.

Minerals especially calcium play an important role in carapace formation of crustaceans [7, 25], in addition to the role of magnesium and phosphorous during molting [26], but they are present in freshwater crustaceans by small portions compared with marine and marine-terrestrial crustacean animals. Calcium levels were increased in the haemolymph through premolt sub-stages and postmolt stages indicates the reabsorption from old carapace and redeposition again after an ecdysis in a new 
exoskeleton which is in full agreement with that mentioned by Warner [7], Highnam and Hill [25], Wilder et al. [27], Amer [28]. Calcium fluctuations may be attributed to the effect of both molting hormone of $\mathrm{Y}$ - organ and neurosecretory hormones of the eye-stalk organs (X-organ) on the metabolism and both reabsorption and deposition of calcium ions from the carapace to the haemolymph before and after molting [25]. They also added that, the eye-stalk neurosecretory hormones regulate calcium mobilization, while crustecdysone dissolute the organic matrix of the cuticle and in consequence, its associated minerals content leading to increase in haemolymph concentrations of these minerals and other constituents. Also the increasing of calcium in haemolymph in narrow range indicating that haemolymph is not storage organ in the freshwater crustacean species [26].

Although, Niyogi and Wood [29] reported that metals penetrate aquatic species in chemical form, not as free ions. Changes of minerals measured in haemolymph during molting stages were nearly fluctuated but it increased slightly during premolt and postmolt stages indicating that haemolymph is just a carrier. While, Sparkes and Greenway [30] reported that Holthuisana transversa utilizes the haemolymph as a storage site for those ions reabsorbed from the cuticle in premolt stage.

Moreover, hepatopancreas plays an important role during molting process and considers a main storage site for the most important inorganic and organic components needed to success this process [31]. The midgut gland (hepatopancreas) acts as a main storage site for calcium in most marine crabs [32] and in fresh water crab Paretelphusa hydrodromus [33]. The present results showed that, calcium levels in hepatopancreas rises in premolt sub-stages significantly than intermolt stage. But it decreased sharply in postmolt stages A and B indicating it's storing in hepatopancreas during premolt substages, then reabsorbed in postmolt stages to mineralize the new cuticle. These results agree well with those mentioned by Warner [7], Greenway [26], Brannon \& Rao [34].

Since phosphorous involved in many physiological processes in crustaceans (energy, phosphorylase system, phospholipids, calcium phosphate [31], it was measured in the hepatopancreas, muscle and haemolymph during the molting cycle of $P$. clarkii. The present study showed that, phosphorous in the hepatopancreas increased during premolt substages $D_{1} \& D_{2}$ but decreased to the minimum just before an ecdysis in premolt substage $\mathrm{D}_{4}$, then increased again in postmolt stage $\mathrm{A}$. This may be due to consuming it for energy during molting or it may be related to formation of some components as mentioned by Florkin and Scheer [35]. They reported that pyrophosphatase activity (polysaccharide synthesis) increases in hepatopancreas during premolt substages $\mathrm{D}_{1}, \mathrm{D}_{2}$ and decreases sharply in $\mathrm{D}_{4}$.

Calcium and phosphorous were fluctuated in narrow range in crayfish abdominal muscle during intermolt stage and premolt substages but they showed low values during postmolt stages. This may be due to voracious needing in mineralization of new cuticle during this stage. Similar observations were found by Florkin and Scheer [35]. However, magnesium was also involved in molting cycle through mineralization of cuticle [26] and phosphorylase system as co-factor [35]. It was noticed that magnesium concentrations in hepatopancreas takes the same pattern of phosphorous, due to its role in these processes during the course of molting cycle.

\subsection{Changes in Major Organic Components}

Results in Table (2) show the percentages of total proteins and total cholesterol in hepatopancreas, muscles and haemolymph of the crayfish, $P$. clarkii during different molting stages. The values of these components are illustrated as following:

Table2. Changes in total proteins and total cholesterol within hepatopancreas, muscles and haemolymph of the cray fish, procamborus clarkii during the molting stages.

\begin{tabular}{|c|c|c|c|c|c|c|c|}
\hline \multirow{2}{*}{\multicolumn{2}{|c|}{$\begin{array}{c}\text { Parameters } \\
\text { Molting stages }\end{array}$}} & \multicolumn{3}{|c|}{ Total protein (mg\%) } & \multicolumn{3}{|c|}{ Total cholesterol (mg/100g) } \\
\hline & & \multirow{2}{*}{$\begin{array}{c}\text { Hepatopancreas } \\
20.69 \\
\pm 5.01\end{array}$} & \multirow{2}{*}{$\begin{array}{c}\text { Muscles } \\
10.40 \\
\pm 1.44\end{array}$} & \multirow{2}{*}{$\begin{array}{l}\text { Haemolymph } \\
\begin{array}{c}10.00 \\
\pm 1.18\end{array}\end{array}$} & \multirow{2}{*}{$\begin{array}{c}\text { Hepatopancreas } \\
80.43 \\
\pm 11.88\end{array}$} & \multirow{2}{*}{$\begin{array}{c}\text { Muscles } \\
28.71 \\
\pm 5.76\end{array}$} & \multirow{2}{*}{$\begin{array}{c}\text { Haemolymph } \\
17.30 \\
\pm 1.53\end{array}$} \\
\hline $\begin{array}{l}\text { Inter- } \\
\text { molt }\end{array}$ & $\mathrm{C}$ & & & & & & \\
\hline \multirow{3}{*}{ Pre-molt } & $\mathrm{D}_{1}$ & $\begin{array}{l}17.15 \\
\pm 3.14\end{array}$ & $\begin{array}{l}11.05 \\
\pm 1.21\end{array}$ & $\begin{array}{l}11.31 \\
\pm 0.63\end{array}$ & $\begin{array}{l}59.74 \\
\pm 7.07\end{array}$ & $\begin{array}{l}37.68 \\
\pm 8.75\end{array}$ & $\begin{array}{l}16.56 \\
\pm 1.91\end{array}$ \\
\hline & $\mathrm{D}_{2}$ & $\begin{array}{l}20.78 \\
\pm 5.04\end{array}$ & $\begin{array}{l}12.15 \\
\pm 2.02\end{array}$ & $\begin{array}{l}11.95 \\
\pm 2.80\end{array}$ & $\begin{array}{c}59.90 \\
\pm 11.58\end{array}$ & $\begin{array}{c}39.32 \\
\pm 13.71\end{array}$ & $\begin{array}{l}12.74 \\
\pm 1.27\end{array}$ \\
\hline & $\mathrm{D}_{3}$ & $\begin{array}{r}22.86 \\
\pm 3.45\end{array}$ & $\begin{array}{c}8.90 \\
\pm 0.83\end{array}$ & $\begin{array}{r}12.50 \\
\pm 2.24\end{array}$ & $\begin{array}{l}46.74 \\
\pm 6.41\end{array}$ & $\begin{array}{l}21.84 \\
\pm 7.24 \\
\end{array}$ & $\begin{array}{l}21.66 \\
\pm 1.91 \\
\end{array}$ \\
\hline
\end{tabular}


Change in Organic and Inorganic Components of Hepatopancreas, Muscles and Haemolymph of Procambarus clarkii during the Molting Cycle

\begin{tabular}{|c|c|c|c|c|c|c|c|}
\hline \hline & \multirow{2}{*}{$\mathrm{D}_{4}$} & 19.60 & 11.52 & 9.76 & 77.78 & 33.57 & 28.66 \\
& & \pm 6.69 & \pm 1.51 & \pm 0.04 & \pm 12.96 & \pm 7.01 & \pm 0.64 \\
\hline & \multirow{3}{*}{$\mathrm{A}$} & 19.52 & 10.05 & 13.82 & 53.86 & 28.02 & 31.46 \\
Post- & $\mathbf{A}$ & $\mathbf{4} .22$ & \pm 2.93 & \pm 6.53 & \pm 18.12 & \pm 2.42 & \pm 1.65 \\
\cline { 2 - 8 } molt & \multirow{2}{*}{$\mathrm{B}$} & 18.49 & 8.27 & 12.50 & 74.76 & 21.74 & 36.31 \\
& & \pm 4.21 & \pm 1.56 & \pm 2.83 & \pm 1.11 & \pm 6.43 & \pm 10.19 \\
\hline
\end{tabular}

\subsubsection{Total Proteins}

\section{- $\quad$ Changes in the Hepatopancreas During Molting}

Data (Table 2) revealed that, the maximum value of total proteins in hepatopancreas was recorded during late premolt substage $\mathrm{D}_{3}(22.86 \pm 3.45 \mathrm{mg} \%)$. It decreased gradually to $19.6 \pm 6.69 ; 19.52 \pm 4.22$ and $18.49 \pm 4.21 \mathrm{mg} \%$ during the premolt substage $\mathrm{D}_{4}$; post molt stage $\mathrm{A}$ and post molt stage $\mathrm{B}$, respectively. However, the minimum ratio of total proteins $(17.15 \pm 3.14 \mathrm{mg} \%)$ was recorded in the early premolt substage $\mathrm{D}_{1}$. The statistical analysis using student $\mathrm{T}$-test showed non significant differences between its values during the intermolt stage $\mathrm{C}$ and other stages and substages, but the present results were favor to be increased slightly during late premolt substage $D_{3}$ in the hepatopancreas (Tables 3).

\section{- Changes in the Muscles During Molting}

Results (Table 2) showed the maximum ratio of total proteins in the muscle during the premolt substage $\mathrm{D}_{2}(12.15 \pm 2.02 \mathrm{mg} \%)$, but declined gradually to $11.52 \pm 1.51 \mathrm{mg} \%$ during the late premolt substage D4 and reached its minimum value $8.27 \pm 1.56 \mathrm{mg} \%$ in the recently molt stage B. It increased again to $10.05 \pm 2.93 \mathrm{mg} \%$ during the newly molt stage A, but without any significant differences between these all values during the different molting stages (Table 3 ).

\section{- $\quad$ Changes in the Haemolymph During Molting}

The percentages of total proteins in haemolymph of $P$. clarkii were very similar to those recorded in the muscles, but being slightly lower than of hepatopancras. Total protein ratios increased gradually from $11.31 \mathrm{mg} \%$ to $11.95 \mathrm{mg} \%$ and reached $12.50 \mathrm{mg} \%$ during substages $\mathrm{D}_{1} ; \mathrm{D}_{2}$ and $\mathrm{D}_{3}$, respectively. But declined to the minimum value $(9.76 \pm 0.04 \mathrm{mg} \%)$ during the late premolt substage $\mathrm{D}_{4}$ and increased again to $13.82 \pm 6.53 \mathrm{mg} \%$ in the newly molt (postmolt stage A); then showing slight decline $(12.50 \pm 2.83 \mathrm{mg} \%)$ at the postmolt stage B (Table 2). The statistical analysis using T-test showed non significant differences between total proteins in all stages (Table 3 ).

The present study declared that, total proteins of crayfish, $P$. clarkii was ranged between 9.76$13.82 \mathrm{mg} / \mathrm{dl}, 8.27-12.15 \mathrm{mg} \%$ and $17.15-22.86 \mathrm{mg} \%$ in haemolymph, muscle and hepatopancreas, respectively, which are very close to that recorded by Amer [28], Holland et al. [36], El-Mossalami and Emara [37], Zaghlol and Eltadawy [38] averaged 15.6, 14.9 and $13.88 \mathrm{mg} \%$ in muscles of the same species, respectively. It was slightly higher than $10.97 \%$ recorded in true crab Scylla serrate [39]. But, Mona et al. [40] detected higher percentage of protein up to $62.2 \%$ in the same species.

It was noticed that the maximum percentage of protein content recorded in hepatopancreas during premolt sub-stage $\mathrm{D}_{3}$ and in haemolymph during postmolt stage $\mathrm{A}$, indicating its storage in mid gut gland during premolt stage and reabsorbed during postmolt stage to be involved in formation of new cuticle, epicuticle lipoprotein. These findings were in agreement with Skinner [41], Richard [42], Durliat \& Vranckx [43].

Also, the minimum ratio of total protein in the hepatopancreas were recorded in the early premolt substage $\mathrm{D}_{1}$ indicating the possible role of hepatopancreas in synthesizing enzymes necessary for the reabsorption of old cuticle and synthesis of the new. From another point of view, total proteins were decreased in muscles during premolt substage $\mathrm{D}_{3}$. This may be due to protein degradation to help for removing large mass of tissue through the narrow basal joint during an ecdysis [41,44]. But it was observed that total proteins increased again in premolt substage $\mathrm{D}_{4}$, it is probably due to synthesis of enzymes responsible for the degradation of the muscle tissue.

\subsubsection{Total Cholesterol}

\section{- $\quad$ Changes in the Hepatopancreas During Molting}

The highest ratio of total cholesterol in the hepatopancreas was observed during the intermolt stage $\mathrm{C}$ $(80.43 \pm 11.88 \mathrm{mg} / 100 \mathrm{~g})$. It declined to the lowest one $(46.74 \pm 6.41 \mathrm{mg} / 100 \mathrm{~g})$ during the late premolt 
substage $\mathrm{D}_{3}$. However, it increased again to $77.78 \pm 12.96 \mathrm{mg} / 100 \mathrm{~g}$ and $74.76 \pm 1.11 \mathrm{mg} / 100 \mathrm{~g}$ during late premolt substage $\mathrm{D}_{4}$ and recently molt stage $\mathrm{B}$, without any significant difference between the two stages (Tables $2 \& 3$ ).

\section{- Changes in the Muscles During Molting}

The results in Table (2) exhibited irregular changes in the levels of total cholesterol within the muscles of $P$. clarkii during different molting stages. The maximum values $(37.68 \pm 8.75$ and $39.32 \pm 13.71 \mathrm{mg} / 100 \mathrm{~g}$ ) were recorded during the premolt substages $\mathrm{D}_{1}$ and $\mathrm{D}_{2}$, respectively. It decreased sharply during the recently molt stage B $(21.74 \pm 6.43 \mathrm{mg} / 100 \mathrm{~g})$. Statistically, there are non significant differences between all stages of the molting cycle (Table 3 ).

\section{- Changes in the Haemolymph During Molting}

Data (Table 2) revealed that, total cholesterol was remarkably increased during the premolt substages from $16.56 \pm 1.91$ at $\mathrm{D}_{1}$ to $28.66 \pm 0.64 \mathrm{mg} / \mathrm{dl}$ at $\mathrm{D}_{4}$. It reached the maximum value $(36.31 \pm 10.19 \mathrm{mg} / \mathrm{dl})$ during the recently molt stage $B$ and declined sharply into the lowest one $(12.74 \pm 1.27 \mathrm{mg} / \mathrm{dl})$ during the premolt substage $D_{2}$. The statistical analysis in Table (3) showed that, there is a significant difference $(\mathrm{P}<0.05)$ between the intermolt stage $\mathrm{C}$ versus the late premolt substage $\mathrm{D}_{4}$, newly molt $\mathrm{A}$ and $\mathrm{B}$.

Total cholesterol is very important for ecdysone (molting hormone) synthesis [25] and hepatopancreas is the major storage organ $[\mathbf{7 , 8 , 1 7 ]}$. The present results showed total cholesterol level decreases in hepatopancreas during premolt sub-stages and increases in hamolymph during the same stage. These results indicated that, total cholesterol in hepatopancreas may be used for ecdysone synthesis.

In spite of hepatopancreas and haemolymph are the most important tissues concerned in the molting cycle, there are also changes occurring in muscle tissue $(\mathbf{3 1}, \mathbf{4 4}]$. In contrast, the maximum mean of total cholesterol content in abdominal muscle of $P$. clarkii was $39.32 \pm 13.71 \mathrm{mg} / 100 \mathrm{~g}$ during premolt stage and the minimum level was recorded during postmolt stage B. These results were slightly close to Zaghlol and Eltadawy [38] who reported that the crayfish P. clarkii contains lowest cholesterol content in compared with egg, prawns, shrimp, lobster, Atlantic salmon which contain 250, 195, 130, , $50-100,56 \mathrm{mg} / 100 \mathrm{~g}$, respectively. However, the higher amounts of total cholesterol $(47.0 \pm 1.5$ $\mathrm{mg} / 100 \mathrm{~g}$ ) were detected by Essien [45] in crayfish, Palaemonets varians.

In contrast, the change in total cholesterol level in haemolymph is greater than would be expected by chance at $\mathrm{D}_{4}$; $\mathrm{A}$ and $\mathrm{B}$ molting stages; there is a statistically significant change $(\mathrm{P}<0.05)$, indicating that incorporation of molting hormone during these stages which act as the main controller of molting cycle and associated external and internal changes.

\section{CONCLUSION AND RECOMMENDATION}

- The molting stages were characterized by internal changes, represented by sharp fluctuations in levels of biominerals organic components in hepatopancreas, muscle and haemolymph which plays an important role in molting cycle.

- Use of this species as a low price protein source for human food.

- Increasing fisheries of this species in the Egyptian freshwater environment leads to mitigate its hazard effects on other faunal components.

- Encourage fisheries for use it locally in several purposes as food for poultry farming, fish meal, experimental animal for researches and training of undergraduate students.

\section{REFERENCES}

[1] Fishar, MR. Red Swamp Crayfish (Procambarus clarkii) in River Nile, Egypt Case Study, Egypt, National Institute of Oceanography and Fisheries. 2006; pp: 34.

[2] Hernández-Vergara MP, Pérez-Rostro C. Advances in Domestication and Culture Techniques for Crayfish Procambarus acanthophorus. Aquaculture. 2012; 308: 217-240.

[3] Huner JV, Lindqvist OV. Special problems in freshwater crayfish egg production. In: Crustacean egg production, (eds. A. Wenner and A. Kuris). 1995; 235-264.

[4] Soliman GN, El-Assal F, Salah El-Deen M, Hamdi SA. The reproductive biology of the red swamp crawfish Procambarus clarkii (Girard, 1852) (Decapoda: Cambridae) in the River Nile, Egypt. Egypt. J. Zool. 1998b; 30: 311-325. 
[5] Rodriguez-Serna M, Carmona-Osalde C, Olvera-Novoa MA, Arredondo-Figueroa JL. Fecundity, egg development and growth of juvenile crayfish Procambarus (Austrocambarus) llamasi (Villalobos 1955) under laboratory conditions. Aqua. Rese. 1999; 31: 173-179.

[6] Kuballa A, Elizur A. Novel molecular approach to study moulting in crustacea, Bull. Fish Res. Agen. 2007; 20: 53-57.

[7] Warner G F.The Biology of crabs. Elek Science, London. 1977; 119-140.

[8] Lowery RS. Growth, molting and reproduction. In: Holdich, D.M., Lowery, R.S. (Eds.), Freshwater Crayfish, Biology, Management and Exploitation. Croom Helm Press, London. 1988; 83-113.

[9] Hartnoll RG. Growth in Crustacea-twenty years on, Kluwer Academic Publishers, Hydrobiologia. 2001; 449: 111-122.

[10] Promwikorn W, Kirirat P, Thaweethamsewee P. Index of molt staging in the black tiger shrimp (Penaeus monodon) Songklanakarin J. Sci. Technol. 2004; 26 (5): 765-772.

[11] Ibrahim AM, Emam WM, Mubarak MF, Beltagy SM, Tharwat AA. On the reproductive biology of the crayfish Procambarus clarkii in Egypt. J. Egypt Acad. Soc. Environ. Develop. 2006; 7 (1): $145-171$.

[12] Habashy MM. Survival and growth rates of procambarus clarkii, Girard Crastacea, Decapoda) under different temperature and salinity levels. J. Egypt Ger. Soc. of Zoo. 2004; 43 (D):135 146.

[13] Ibrahim AM, Emam WM, Beltagy SM, Tharwat AA, Mubarak FM. On some factor affecting molting of the crayfish procambarus clarkii from the River Nile Egypt. J. Environ. Sci. 2000; 1(1): 23-45.

[14] Hamdi SA. Studies on the red swamp crawfish Procambarus clarkii (Girard, 1852) (Decapda: Camaridae) in the River Nile, Egypt. M. Sc.,Thesis, Fac. Sci., Cairo Univ. 1994; 136 pp.

[15] Soliman GN, El-Assal F, Salah El-Deen M, Hamdi SA. Habitat, distribution and behaviour of the red swamp crawfish Procambarus clarkii (Girard, 1852) (Decapoda: Cambridae) in the River Nile, Egypt. Egypt. J. Zool. 1998a; 30: 297-310.

[16] Mubarak MF. Fishery management of the exotic crayfish, Procambarus clarkii in the irrigation canal system of the River Nile, Egypt. Ph.D. Thesis, Institute of Environmental Studies and Researches, Ain Shams Univ. 2001; 160 pp.

[17] Chang ES. Physiological and biochemical changes during the molt cycle in decapod crustaceans. J. Experi. Marine Biol. and Ecol. 1995; 193: 1-14.

[18] Ahearn GA, Mandal PK, Mandal A. Calcium regulation in crustaceans during the molt cycle: a review and update. Compar. Biochem. Physiol.2004; 137: 247-257.

[19] Doumas BT. Colorimetric determination of total protein for serum or plasma; Clin. Chem. 1975; 21 (8): $1159-1166$.

[20] Naito, H. K. (1984): Cholesterol. Kaplan, A. et al. Clin Chem the C.V. Mosby Co. St. Louis. Toronto. Princeton, 1194-1206.

[21] Daly JA, Ertingshausen G. Direct method for determination of inorganic phosphate in serum with the centrifi. chem. Clin. Chem.1972; 18: 263.

[22] Cowley DM, Clin H. Colourimetrical method for estimation of calcium, Chem.1986; 32: 894.

[23] Thomas L. Clinical Laboratory Diagnosyics $1^{\text {st }}$ ed Frankfurt: Th-Books Vertagsgesells chaft. $1998 ; 231-241$.

[24] Ibrahim AM, Khalil MT. The red swamp crayfish in Egypt. (A fast spreading freshwater invasive crustacean), Egypt, Centre of Researsh \& Studies of Protectorates, Ain Shams Univ.2009; (1): pp 153.

[25] Highnam KC, Hill L. The comparative endocrinology of the invertebrates. (English Language Book Society) first edition. 1969; 298 pp.

[26] Greenway P. Calcium balance and moulting in the crustacea, Great Britain, Biol. Rev. 1985; 60: 425-454. 
[27] Wilder MN, Huong DT, Jasmani S, Jayasankar V, Kaneko T, Aida K, Hatta T, Nemoto, S, Wigginton A. Hemolymph osmolality, ion concentrations and calcium in the structural organization of the cuticle of the giant freshwater prawn Macrobrachium rosenbergii: Changes with the molt cycle. Aquaculture. 2009; 292: 104-110.

[28] Amer MA. Temporal and spatial changes in contents of organic and inorganic components during molting of the freshwater crayfish, Procambarus clarkii. Ph.D. thesis, Zool. Dept., Fac. of Science, Al-Azhar Univ. 2015; 191pp.

[29] Niyogi S, Wood CM. Effects of chronic waterborne and dietary metal exposures on gill metal binding: Implications for the biotic ligand model. Human and Ecological Risk Assessment. 2003; 9: 813-846.

[30] Sparkes S, Greenway P. The haemolymph as a storage site for cuticular ions during premolt in the fresh water/land crab Holthuisana transversa, Great Britain, J. exp. Biol. 1984; 113: 43-54.

[31] Yamaoka LH, Scheer BT. Chapter: 11: Chemistry of growth and development in crustaceans. In: Chemical Zoology; Academic Prees, London. 1970; V (A): 321-338.

[32] Sather BT. Studies in calcium and phosphorous metabolism of the crab Podophthalmus vigil (Fabricus). Pacific Science. 1967; 21: 199-209.

[33] Adiyodi RG. Calcium cycle and the hepatopancreas in the fresh water crab, Patelphusa hydrodromus (herbst). J. Kerala Acad. of Biol. 1969; I: 20-28.

[34] Brannon AC, Rao KR. Barium, strontium and calcium levels in exoskeleton, hepatopancreas and abdominal muscle of the grass shrimp Palaemonetes Pugio: relation to the molting and exposure to barite. Comparative Biochem. Physiol. 1979; 63 (A): 261-274.

[35] Florkin M, Scheer BT. Chemical Zoology. Academic Press New York and London. 1970; V (A): pp 419.

[36] Holland B, Brown J, Buss PH. Fish and Fish products, the third supplement to Mc Cance \& Widdowson's. The composition of food (5thedition), HMSO, London.1993.

[37] El-Mossalami MK, Emara MT. Safety and quality of fresh water crayfish Procamburus clarkii in river Nile. Nahrung. 1999; 43 (2): 126-8.

[38] Zaghlol NF, Eltadawy F. Study on chemical quality and nutrition value of freshwater crayfish Procambarus clarkii, Egypt, J. Arab. Aqua. Soci. 2009; 4 (1): 1-18.

[39] Rameshkumar SG, Ravichandran G, Kaliyavarathan T, Ajithkumar T. Comparison of Protein Content in the Haemolymph of Brachyuran Crabs. Middle-East J. of Scientific Res. 2009; 4 (1): 32-35.

[40] Mona MH, Geasa NM, Sharshar Kh M, Morsy EM. Chemical composition of freshwater crayfish (Procambarus clarkii) and its nutritive value. Egypt. J. Aquat. Biol. And Fish. 1999; 4 (1): $19-34$.

[41] Skinner DM. The structure and metabolism of a crustacean integumentary tissue during a molt cycle, Ph.D., Depart. of Physiol. and Biophysics, New York Univ. School of Medicine,. 1965.

[42] Richard AG. Studies on arthropod cuticle. 7. Patent and masked carbohydrate in the epicuticle of insects. Science. 1980; 115: 206-208.

[43] Durliat M, Vranckx R. Proteins of aqueous extracts from the hepatopancreas of Astucus leptodactyfus. In Changes in proteins during the molt cycle. Comp. Biochem. Physiol. 1982; 71(B): 155-163.

[44] Skinner DM. Interacting factors in the control of the crustacean molt cycle. Amer. Zool. 1966; 25: 275-284.

[45] Essien EU. Lipid content and fatty acid profiles of some lesser knon Nigerian food. J. of food biochem. 1995; 19 (3): 153. 